\title{
Osler Centenary Papers: Osler, inscribed
}

\author{
Mary K K Hague-Yearl (1) 1,2
}

'Department of Social Studies of Medicine, McGill University, Montreal, Quebec, Canada 2Osler Library of the History of Medicine, McGill University, Montreal, QC, Canada

\section{Correspondence to} Dr Mary K K Hague-Yearl, Osler Library of the History of Medicine, McGill University, Montreal, QC, Canada: mary.yearl@mcgill.ca

Received 3 May 2019 Revised 6 July 2019 Accepted 8 July 2019
Check for updates

(C) Author(s) (or their employer(s)) 2019. No commercial re-use. See rights and permissions. Published by BMJ.

To cite: Hague-Yearl MKK. Postgrad Med J

2019:95:637-641.

\section{ABSTRACT}

Background As the centenary of Sir William Osler's death approaches on 29 December 2019, it is worth pausing to reflect on the relationship between the Osler Library of the History of Medicine at McGill University and the image of William Osler, for the two are arguably inextricable. When Osler died he had not yet completed his library, yet his donation to McGill included nearly 8000 volumes that represented the foundations of western medicine. The Osler Library now boasts over 100000 titles and is recognised globally as a centre for the study of medical history.

Methods The approach taken here was to examine inscriptions in the books that William Osler bequeathed to the McGill Medical Facultyin order to learn more about William Osler, the man.

Results By examining inscriptions William Osler and others made in his books, it was possible to learn more about how Osler interacted with his friends, his patients, and also his books.

Conclusion It is argued that these inscriptions are as instructive as they are enriching. They reveal information about Osler's priorities and his personal and professional relationships; future scholars will likely find it useful to examine inscriptions more broadly, to gain insight into such topics as the book trade and world events.

\section{OVERVIEW}

Sir William Osler is arguably one of the most studied medical men of the modern age. Thanks to the honours and remembrances offered over decades by friends and colleagues, Osler-the physician, the teacher, the pathologist-is a familiar figure to many. ${ }^{1-3}$ Despite the impressive corpus of Osler studies, there remain areas worthy of examination. The focus of this investigation is on the inscriptions, letters and other notes found in the books that constituted the original 'Bibliotheca Osleriana' (ie, the nearly 8000 works donated to the McGill Medical Faculty by William Osler, which is described in greater detail below). The information inscriptions impart is intimate, even when pertaining to transactional information such as that about provenance. Moreover, inscriptions in books are worth examining because they are often noticed in passing, but not noted. They are captured during digitisation, yet often overlooked in favour of printed text. Those considered here are primarily of a personal nature, but there are numerous other inscriptions that bear witness to world events; for instance, after Osler purchased Conrad Gessner's Opera botanica in Zurich in 1917, he noted, "I had great difficulty in getting the volumes through, but the Foreign Office in Berne kindly sent them." 4
Sir William Osler was, and continues to be, wellknown for his bibliophilic tendencies (figure 1). ${ }^{5-7}$ How could those inspired by him not take up the investigation invited by his pronouncement that, "A library represents the mind of its collector, his fancies and foibles, his strength and his weakness, his prejudices and preferences." ${ }^{8}$ So it is that we come to know Osler, the man, through his books and via his writings about them. The sentiment expressed nearly 50 years after Osler's death is even more true as we mark the centenary of his passing: 'as the number of those who knew him personally has diminished, and the practice of medicine has made advances of which his generation never dreamed, memories of his personality and scientific pursuits might have faded-were it not for the wellstocked Osler Library of the History of Medicine at McGill University. ${ }^{9}$

\section{THE BEGINNINGS OF THE OSLER LIBRARY}

I am glad to be able to send this beautiful copy of the first edition to the library of my old school, in which anatomy has always been studied in the Vesalian spirit - with accuracy and thoroughness. ${ }^{10}$

So wrote William Osler in a letter from Rome, dated 9 March 9, 1909, which accompanied his gift to the McGill Medical Library of a first edition of Andreas Vesalius's De humani corporis fabrica (Basel, 1543). This donation was an overture to his alma mater, but it was not Osler's first expression of interest in its library. His involvement with the McGill Medical Library had begun during his student days and he continued to cultivate this connection as his professional status grew. What had been an occasional but consistent interest reached an urgency following the 1907 fire that destroyed the Medical Building and much of the library therein. On that occasion, Osler unsuccessfully petitioned John D. Rockefeller for funds to help rebuild and was actively involved in the Faculty's restoration, with special attention paid to the library. $^{11}$

The gift of Vesalius arguably had a deeper significance. The letter that accompanied the book, which now lives inside its front cover, outlined Osler's views on the significance of De fabrica (as it is popularly known) as "the first modern treatise on anatomy based upon dissections of the human body." He admitted 'grave mistakes of omission and of commission' but there was no doubt in Osler's mind: De fabrica was groundbreaking in moving away from Galen, who had committed understandable errors by attempting to describe human anatomy based on animal dissection. As Osler remarked in his letter, Vesalius overturned the gospel of Galen. Accompanying his personal copy of De fabrica, Osler further opined that Vesalius's 


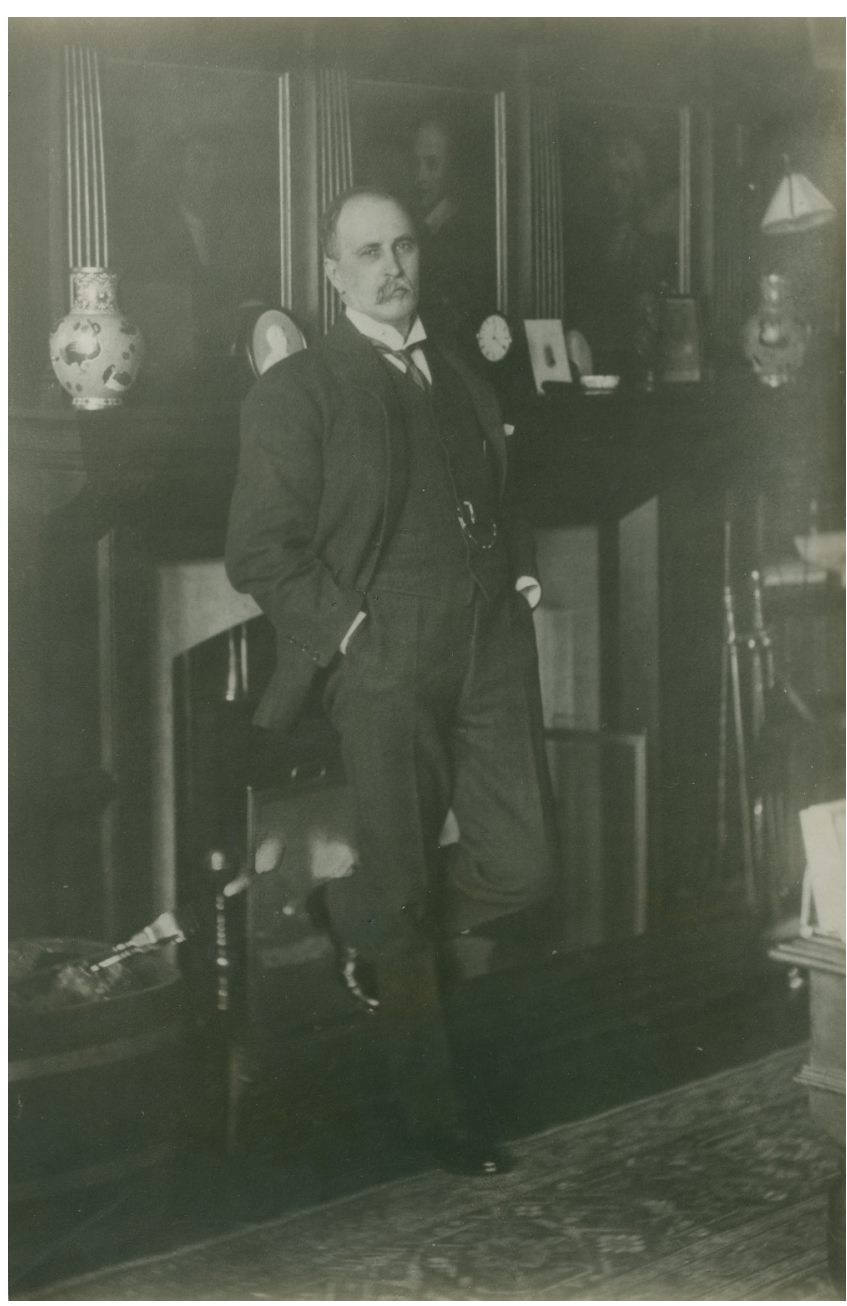

Figure 1 William Osler in front of the three medical humanistsThomas Linacre, William Harvey and Thomas Sydenham —in his library at 13 Norham Gardens, Oxford. CUS_064-017A_P. Image courtesy of the Osler Library of the History of Medicine.

tome represented 'the first modern work of a creator' in contrast to his predecessors who were 'transmutors or transmitters'. ${ }^{10}$ This summation of Vesalius's place in the history of medicine reveals much about Osler's commitment to building a comprehensive medical history library, of which Vesalius would be the cornerstone.

Nearly 2 $\frac{1}{2}$ years after Osler thanked McGill through his gift of De fabrica, he laid out his plans for the Bibliotheca Osleriana. Bibliotheca Osleriana was Osler's own name for the corpus of works he collected and curated with the express intention of making a bequest to his alma mater. On 1 October 1911, William Osler signed a deed of gift agreement that set the stage for the establishment of the Osler Library of the History of Medicine. The deed of gift was simple and to the point: "In recognition of the many kindnesses shown to me as a student and professor at my old school I have for many years collected for its library. By this Deed of Gift I hereby hand over to McGill University for its medical faculty the following,"12 after which comment he described the organisation of his library. The Bibliotheca Osleriana was to be divided into eight sections: the first, or 'Bibliotheca Prima', comprised works that lay the foundations for the history of science and medicine; in the 'Bibliotheca Secunda', he included authors he regarded as important, but whose contributions were less central than those in the Bibliotheca Prima; from there, he moved outwards, to literary works by medical men, historical works, biography, bibliography and finally to sections devoted to incunabula and to manuscripts. ${ }^{8}$ Osler assigned a number to each entry, referring to an item's placement within the catalogue; to this day, each item that arrived as part of Osler's original bequest is identified by a 'B.O.' (Bibliotheca Osleriana) number. Although Osler did not complete his intended catalogue before his untimely death, he had made considerable headway and the notes in his books reveal the extent to which he was invested in this project. The 7668 titles listed in Osler's eight sections of the Bibliotheca Osleriana (7787 with addenda) form a firm foundation for the study of the history of medicine; the library now has over 100000 titles, which support active teaching, research and outreach programmes.

Osler placed two conditions on his gift: that the books be kept together, and that 'members of the profession shall have free access to them for purposes of study'. ${ }^{12}$ The appreciation Osler had for McGill was reciprocated. In a letter dated 15 August 1922, McGill University Secretary A.P.S. Glassco wrote to Francis McLennan of the Board of Governors regarding costs associated with setting up the Osler Library, as proposed by architect Percy Nobbs. Glassco noted that Principal Arthur Currie had at first thought the price too high, but had changed his mind. The opinion, as conveyed by Glassco, was that "The Osler Library ... is really invaluable. As far as we know there is no other library of the kind which can be compared with it. The Principal, therefore, thinks it fitting that the space allotted for it should be properly fitted and furnished."13 It is worth highlighting that while the Osler Library was foremost a gift to McGill, it was also a gift to Canada, which had become a dominion when Osler was a young man. After acknowledging his gratitude to his alma mater, he added, "Then there is the natural feeling of loyalty to the country of one's birth and breeding." 8

\section{Inscriptions as witness}

In pledging to give his library to the McGill Medical Faculty, Osler was promising to donate a significant part of himself. While he had long been known as a bibliophile, book collecting was a defining part of his later years. The building of the library was deeply personal to William Osler, and Osler's continued presence within the library extends beyond his ashes that rest in the Osler Niche. Residing subtly within book inscriptions are parts of the man that, when brought together, form a tangible impression.

One work that reveals something about Osler's character is the library's 1662 edition of Descartes' De homine figuris. An opening flyleaf contains a curious Latinised version of Osler's name, in writing definitively not Osler's. Beneath 'E libris Gulielmi Osler 1914' was a note in Osler's hand, 'Given to me viii.16.14 by C.S. Sherrington' (figure 2). ${ }^{14}$ Those two notes in themselves do not suggest that there is a great story behind them; they appear to be confirmations of a transaction. On the opposing leaf, however, Osler's close second-cousin and the first Head of the Osler Library, W.W. Francis, pasted in an explanation:

After Osler's death Sherrington got this book off the shelf, brought it to me with a twinkle in his eye, o told me he had LENT it to O. in 1914. About 1916 he found the book when O. was out, saw that O. had written ... 'Given to me ...' hadn't the heart to disillusion him, and so he (S.) added the 'E libris...' acquiescing in the expropriation! $!^{14}$

Francis's account enriches the ownership inscriptions and provides further insight into Osler's personal-professional 


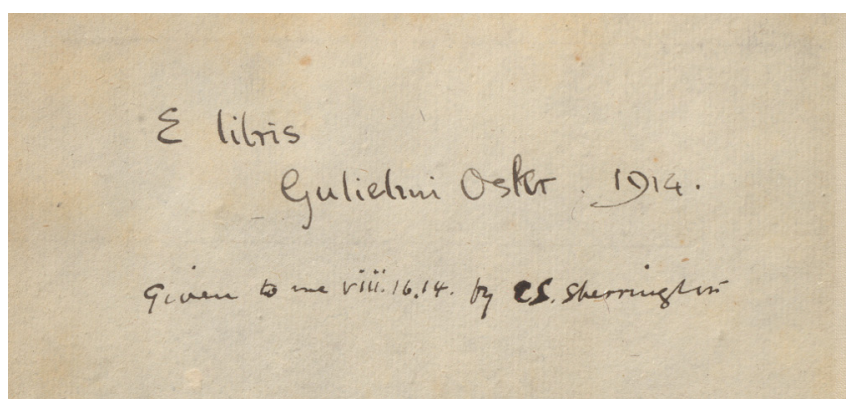

Figure 2 Sherrington's realisation of his 'gift' to Osler of Descartes' De homine figuris (B.0. 931). Image courtesy of the Osler Library of the History of Medicine. B.O., Bibliotheca Osleriana.

relationships. There is a poignancy in his expropriation of the book from Sherrington's library, but also in Sherrington's decision to realise the unintended gift to his friend and colleague. Accompanying Francis's typed note is a handwritten addition revealing that this was not the only book Osler adopted out of Sherrington's library. Macer Floridus, De herbarum virtutibus (Basel, 1559) comes with a similar story. In this volume, Osler wrote, "given to me by my colleague Sherrington, Nov. 1915"15 and yet again Sherrington chose to validate the 'gift' with his own note, "Gulielmo Osler per Car. S. Sherrington, Dec. 1915." 15

There is no small irony in Osler having expropriated Sherrington's books, when a few years earlier-in 1910- he had mused about a former roommate in Montreal, Thomas Davies King, who had taken Osler's copy of Alexander Schmidt's Shakespeare-Lexicon (1875). As the story went, when the work arrived from Berlin, Osler showed it to his roommate, who was a keen devotee of Shakespeare. Osler himself did not see the Lexicon again for 40 years, when he returned to Montreal and asked to see Mr King's Shakespeare collection, by then part of the McGill Library. ${ }^{16}$ There, Osler spotted his copy of the Shakespeare-Lexicon, and inserted into the front cover a typed account dated 15 August 1910. He concluded his story, “... I add this memorandum as an encouragement to elderly bibliophiles to appropriate the books of their good-natured friends." 17

The dynamic sharing of books among friends is a wellrecognised part of Osler's history, to which inscriptions bear witness. He is reported to have inducted Harvey Cushing into the fold of bibliophilia; in return, Cushing sent several works that now reside among Osler's collection. Many bear the simple marks of friendship, such as La metoposcopie, Paris, ${ }^{18}$ 1658 which contains extensive handwritten notes along with an acknowledgement of provenance, 'Given to me at xmas 1904 by Harvey Cushing'. ${ }^{18}$ In Institutionum anatomicum ... Ab Andrea Wesalio (Venice, 1538), there are notes by Harvey Cushing, but also Osler's acknowledgment of where this gift fit within his library project: "Sent 3.x.19 by that dear friend Harvey Cushing who has a duplicate. It helps to complete my collection of the original editions of Vesalius."19

While there is a considerable poignancy in the examples of book exchange with Osler's friends, other inscriptions are revealing of a fond and fun relationship between William Osler and his son, Revere. Within his copy of William Harvey's De motu cordis, ${ }^{20}$ Frankfurt, 1628, Osler reflected that he had been looking for a good copy of the first edition for nearly 10 years before a dealer had found one for him. On a flyleaf at the back of the book is a transcription added by Revere Osler when he was home on leave in March 1916. Devoted as he was to Izaak Walton, Revere had gone to the Bodleian Library to look

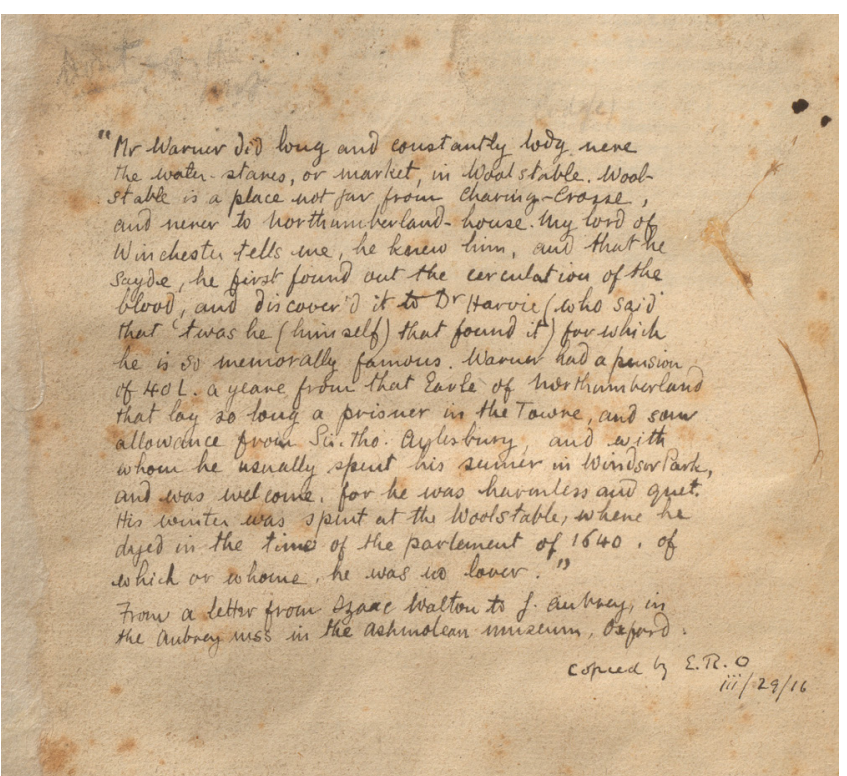

Figure 3 Revere Osler's transcription of Izaak Walton's description of Walter Warner's claim to have discovered circulation. It begins, "Mr Warner did long and constantly lodg nere the water-stares, or market, in Woolstable. Woolstable is a place not far from Charing Crosse, and nerer to Northumberland-house. My lord of Winchester tells me, he knew him, and that he sayde, he first found out the circulation of the blood, and discover'd it to Dr. Harvie (who said that 'twas he (himself) that found it) for which he is so memorally famous." Image courtesy of the Osler Library of the History of Medicine.

at Walton material among the Aubrey Manuscripts. There, he spotted a letter from Izaak Walton to John Aubrey that recounts Walter Warner's claim that, 'he first found out the circulation of the blood, and discover'd it to Dr Harvie (who said that 'twas he (himself) that found it) for which he is so memorially famous' ${ }^{20}$ In other words, Revere Osler copied into his father's edition of De motu cordis an accusation that the work was one of plagiarism (figure 3).

Another illustration of the deeply personal associations that exist in many of Osler's books is found in the volume often recognised as being dearest to Osler. An 1862 printing of Thomas Browne's Religio Medici possesses its own mythology in the story of Osler's development as a book collector and his development as a humanist. Bought as a student at Trinity College, University of Toronto, Osler called this work the 'father of my collection'.

The book itself bears Revere Osler's self-designed bookplate, since Revere had claimed this volume for himself. In a note dated 21 September 1914-3 years after Osler signed his deed of gift to McGill—is the pronouncement: "This copy goes to E.R. Osler, not to McGill." ${ }^{21}$ Two years after Revere was killed in the war and just 3 weeks before Osler himself died, he pencilled additional notes in the book. Dated 6 December 1919, he wrote under his 1914 message, "I doubt if any man can more truly say of this book "comes viae vitaque"" (figure 4). ${ }^{21}$ On the same day, he noted on page 345 , "Wonderful page always impressed me as one of the great ones in B" (figure 5). Here, Browne posited that the majority of great men must be forgotten in time. The state of Osler's health accentuates the poignancy of the specific sentence he marked with an asterisk: "The greater part must be content to be as though they had not been, to be found in the register of God, not in the record of man." 21 


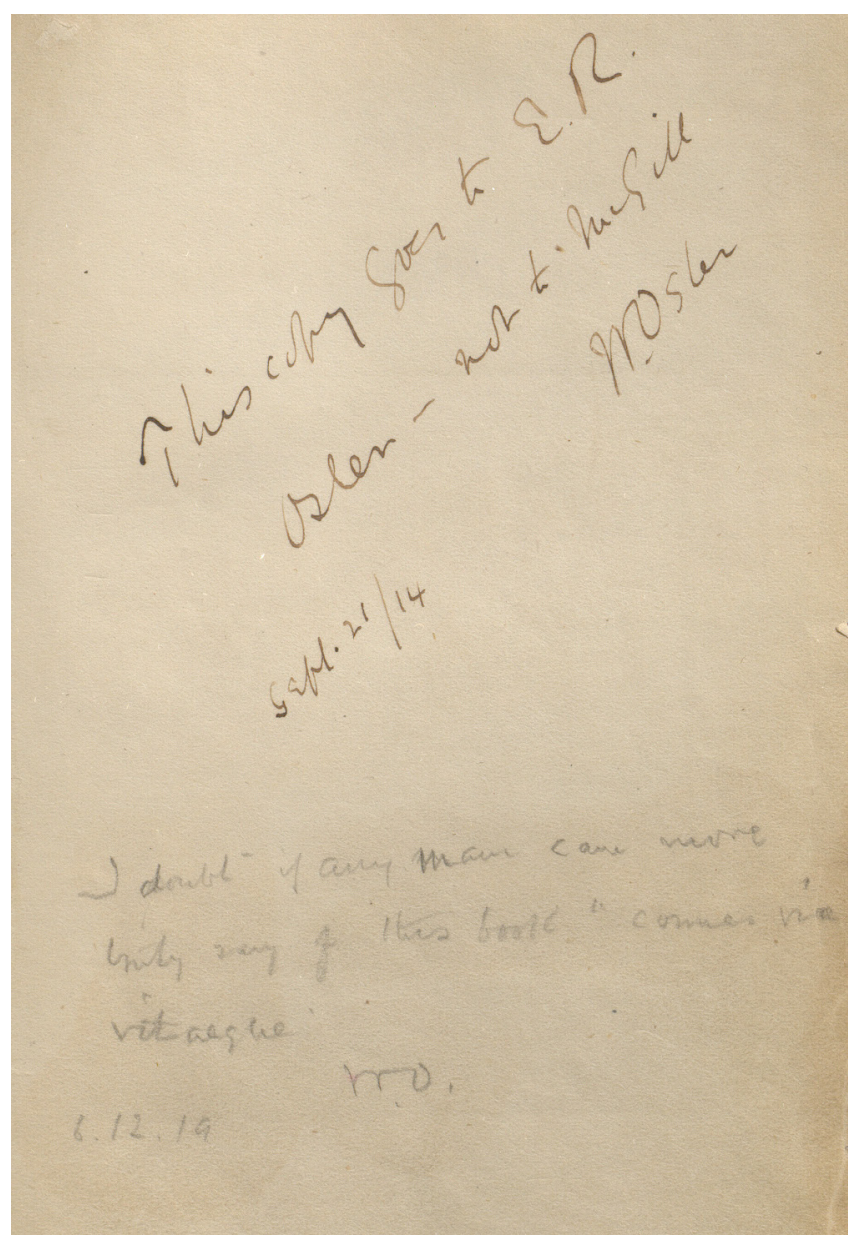

Figure 4 Inscriptions on a front flyleaf, B.0. 4446, Thomas Browne, Religio Medici (Boston, 1862). Image courtesy of the Osler Library of the History of Medicine. B.O., Bibliotheca Osleriana.

Given the profound importance of Religio medici to Osler, it should be no surprise that he received copies as gifts. Some of those made it into his library, but his careful curation means that those that did were included because they had a particular

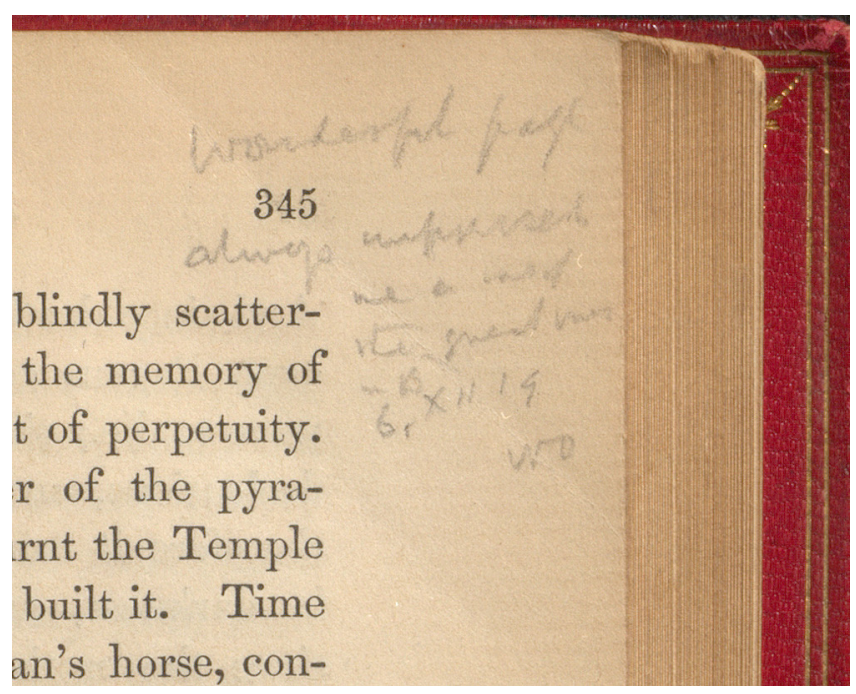

Figure 5 Three weeks before his death, Osler took note of a passage about the lack of enduring legacy enjoyed by most men. Image courtesy of the Osler Library of the History of Medicine. value. One such copy contains a moving letter written by the mother of a young patient of Osler; a flyleaf opposite the letter contains the inscription, "To Sir William Osler, A souvenir from a little boy, May 1914." The letter itself is worth quoting in full, as it illustrates the depth of appreciation that Osler the physician inspired:

\section{Dear Sir William}

I am sending you this little book, which you probably know well. But I hope it will find a place among the books you keep near you that it may remind you of the little boy whose last days you did so much to cheer.

It is just about a year ago that you saved his life. I have been so thankful for those 11 months of close companionship - no doubt it makes the pain worse now, but there are some pains one would not be without.

At the risk of being tiresome I must tell you again how much I feel we owe you - a debt we can never repay. We can only thank God that you are here.

As I sit here I can picture so well how much pleasure it would have given Walter to give you this little book himself.

I am

Affectionately yours

Katbleen Wylie 22

\section{LOOKING FORWARD}

When pieced together, the inscriptions found in William Osler's books form a picture of the man and the world he inhabited. There are some stories that will always be relevant and powerful, such as those that reflect the bond between William and Revere Osler. The concluding pair of inscriptions presented here do not fit into that category. Instead, they are included because they hold a particular resonance to the library at the current time.

In July 2018, a fire broke out on the terrace that sat atop the Osler Library. Despite being spared serious damage, the fire had and continues to have a tremendous impact on the library. While it is well known that the great Baltimore fire of 1905 came close to threatening Osler's home shortly before he moved to Oxford, inscriptions in two of his books are reminders of a more acutely threatening fire (figure 6). In November 1915 a fire in Osler's Oxford home threatened the library, but ultimately affected two volumes. Osler's letters from the time indicate that the fire was a major event. ${ }^{23}$ The inscriptions in the affected books are matter-of-fact in their assessment: "This and another MS were in the dining room

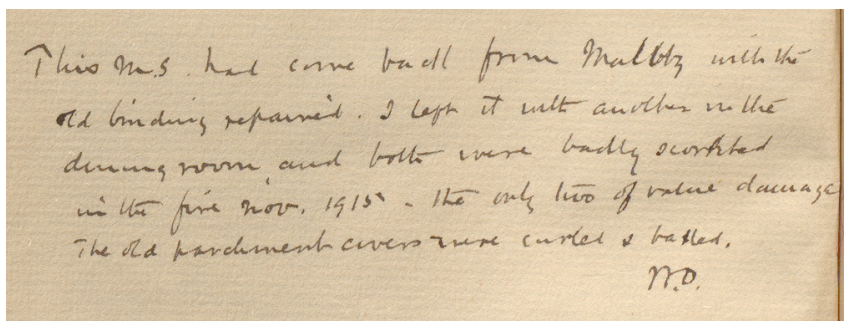

Figure 6 Osler's note in Summa judicialis astronomie ([Spain?, 14]), about the two works of value that were damaged during a house fire in November 1915: "This M.S. had come back from Maltby with the old binding repaired. I left it with another in the dining room, and both were badly scorched in the fire nov. 1915 - the only two of value damaged. The old parchment covers were curled + baked." ${ }^{25}$ The other book referred to was a Paolo Sarpi, Discorso ... sopra la materia dell'Inquisitione. ${ }^{24}$ Image courtesy of the Osler Library of the History of Medicine. 
Nov. 1915, (having just returned from the binder) the night of the fire when the room was burnt out. They were badly scorched and the bindings ruined. W. Osler." ${ }^{24}$ Just over 100 years later, the 'scorched' books are no more noticeable for their drama than are any other books in the library. In 2019, as we celebrate the gift that William Osler made to McGill, the two manuscripts that survived the November 1915 conflagration serve as timely reminders of the resilience of books and of libraries-through time and through fire.

\section{Main messages}

- The inscriptions in William Osler's books create a personal record that does not exist in traditional sources such as letters, personal accounts, and diaries.

- Readers can gain insight into William Osler's personal and professional life by examining inscriptions in his books.

- By examining letters and inscriptions, one can learn about William Osler's priorities with regard to book collecting.

\section{Current research questions}

- What can further study of book inscriptions reveal about the impact of global events, such as war and economic downturn, on the experience of historical individuals studied?

- Can book inscriptions be used to build a character profile of those who wrote them?

- Do book inscriptions present a similar picture of personal relationships to that offered by more traditional sources, such as letters?

\section{What is already known on the subject}

- William Osler was not only a father of modern medicine, he was also a medical humanist who believed that a good doctor should be well-read.

- Bibliophilia was a common theme in William Osler's friendships.

Contributors MKKH-Y is the sole contributor of this article.

Funding The authors have not declared a specific grant for this research from any funding agency in the public, commercial or not-for-profit sectors.
Competing interests None declared.

Patient consent for publication Not required.

Provenance and peer review Not commissioned; externally peer reviewed.

Data availability statement There are no additional data in this work.

ORCID iD

Mary K K Hague-Yearl http://orcid.org/0000-0002-7858-2122

\section{REFERENCES}

1 Abbott ME, Blogg MW, International Association of Medical Museums. Sir William. Osler; Memorial Number: Appreciations and Reminiscences. Montreal: Privately issued, 1926.

2 Bliss M. William Osler: A Life in Medicine. Toronto: University of Toronto Press, 1999.

3 Duffy TP. The Osler-Cushing covenant. Perspect Biol Med 2005;48:592-602.

4 Gessner C. Opera botanica. Nuremberg, 1754-1771. B. 0. 650.

5 Lyons C. "The Touch Divine of Noble Natures Gone": Sir William Osler as a Book Collector (pp 209-232). Papers 2016;53:209-32.

6 Lyons C. From Osler's library to the Osler library of the history of medicine, McGill University, Montreal: an overview. Can Bull Med Hist 2007;24:189-203.

7 McNally PF, Brown G. "Osler SN and Francis: Creating the Bibliotheca Osleriana." William Feindel, Elizabeth Maloney, Pamela Miller, eds. Sir William Osler: The Man and His Books. Montreal: Osler Library of the History of Medicine 2011:25-51.

8 Osler W. "The Collecting of a Library.". In: Francis WW, Hill RH, Malloch A, eds. Bibliotheca Osleriana. A catalogue of books illustrating the history of medicine and science collected, arranged, and annotated by Sir William Osler, Bt. and Bequeathed to McGill University. Clarendon Press: Oxford, 1929.

9 Gray C. "The Osler Library: A Collection that Represents the Mind of its Collector.". CMA Journal 1978;119:1442-5.

10 Vesalius A. De humani corporis fabrica. Basel, 1543. Osler's personal copy, B.0. 567

11 Cushing H. The Life of Sir William Osler. London: Oxford University Press, 1940.

12 Sir William Osler Collection. Ca p100, Osler library archives, McGill University.

13 A.P.S. Glassco to Francis McLennan. "Osler Library, Faculty of Medicine". McGill University Archives, 1922. Acc. No. 640, R.G.4, C.96, 2169 B.

14 Descartes R. De homine figuris. Lyon, 1662: B.0. 931.

15 Floridus M. De herbarum virtutibus. Basel, 1559. B.0.

16 Bensley EH. "The Book the Dr. Osler Lost". Osler Library Newsletter 1972;22:1-2.

17 Schmidt A. Shakespeare-Lexicon: a complete dictionary of all the English words, Phrases and constructions in the works of the poet. Berlin, 1875.

18 La metoposcopie. Paris, 1658. B.0.

19 Institutionum anatomicum.Ab Andrea Wesalio. 1538. B.0. 582. Venice

20 Harvey W. Exercitio anatomica de motu cordis et sanguinis animalibus. Frankfurt, 1628. B.0. 692

21 Browne T. Religio medici. Boston, 1862. B.0. 4446.

22 Browne T. Religio medici. 4471. London, 1911. This volume, housed in Osler Library Niche 3, is a copy of B.O.

23 Osler Letter Index. Available: https://osler-letters.library.mcgill.ca/

24 Sarpi P. Discorso... al serenissimo Doge di Venetia sopra la materia dell'Inquisitione.... [Italy, ca. 1613, B.0. 909.

25 Summa judicialisastronomie [Spain?, 14-]. B.0. 7513. [Spain?, 14-]. B.0 